ENTREPRENEURSHIP AND SUSTAINABILITY ISSUES

ISSN 2345-0282 (online) http://jssidoi.org/jesi/ 2019 Volume 7 Number 1 (September)

http://doi.org/10.9770/jesi.2019.7.1(10)

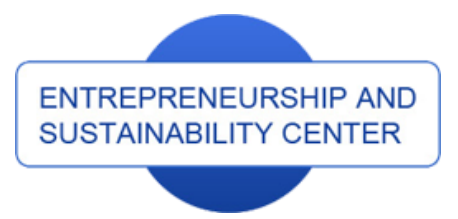

Publisher

http://jssidoi.org/esc/home

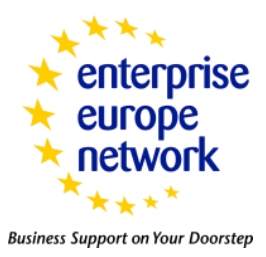

CASPA

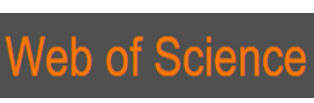

1) Clarivate

\title{
THE RUBLE EXCHANGE RATE AND THE PRICE OF OIL: ASSESSMENT OF THE DEGREE OF DEPENDENCE, ITS CAUSES AND WAYS OF OVERCOMING
}

\author{
Aleksei Anatolievich Ustiuzhanin'1, Irina Aleksandrovna Liman², Elena Petrovna Kiselitsa ${ }^{3}$, \\ Natalia Nikolaevna Shilova ${ }^{4}$, Tatiana Ivanovna Leyman ${ }^{5}$ \\ 1,2,3,5 Tyumen State University, 6 Volodarskiy Street, Tyumen, 625003, Russia \\ ${ }^{4}$ Industrial University of Tyumen, 38 Volodarskiy Street, Tyumen, 625000, Russia \\ E-mails: ${ }^{1}$ ustiuzhanin.a.a@mail.ru ; ${ }^{2}$ liman.i.a@mail.ru ; ${ }^{3}$ Kiselitsa461550@mail.ru ; ${ }^{4}$ shilova.n.n@mail.ru ; \\ 5leyman.t.i@mail.ru
}

Received 11 February 2019; accepted 11 July 2019; published 30 September 2019

\begin{abstract}
This article is an attempt to estimate the impact of the volatility of oil prices on the income of Russian economic entities associated with the oil realization, as well as the importance of the price of oil in stabilizing the exchange rate of the national currency. The authors have analyzed dependencies between the variance of the price of oil, ruble exchange rate against the US dollar and Russian oil export volume and observed the correlation between these indicators. It has been concluded that the problems of the Russian economy are expressed in the loss of dollar revenues from oil sales by 2.37 times in the last five years, which significantly affected the trade balance and served as the basis for the devaluation of the ruble. According to the results of the research, the authors suggest several solutions for raising the price of oil and stabilizing the ruble exchange rate.
\end{abstract}

Keywords: oil price; ruble rate; oil production volume; US dollar rate

Reference to this paper should be made as follows: Ustiuzhanin, A.A.; Liman, I.A.; Kiselitsa, E.P.; Shilova, N.N.; Leyman, T.I. 2019. The ruble exchange rate and the price of oil: assessment of the degree of dependence, its causes and ways of overcoming, Entrepreneurship and Sustainability Issues 7(1): 121-132. http://doi.org/10.9770/jesi.2019.7.1(10)

JEL Classification: F 37

\section{Introduction}

Currently, Russia is going through a crisis period. The low price of oil, the inaccessibility of borrowed capital due to sanctions on several industries, and the growth of costs for the military-industrial complex all combine to impede the development of the economy, increase consumer prices, and reduce the standard of living. However, in this situation, it is important to understand how certain factors affects the economy, to what extent, and for what reason they occur. 


\section{ENTREPRENEURSHIP AND SUSTAINABILITY ISSUES}

ISSN 2345-0282 (online) http://jssidoi.org/jesi/ 2019 Volume 7 Number 1 (September) http://doi.org/10.9770/jesi.2019.7.1(10)

Feklin and Shevelev (2015) concluded that the most significant factor affecting the ruble is the price of oil. This is due to the fact that Russia's monetary policy is largely determined by revenues from the export of oil and gas resources. At the same time, the price of oil is not the only factor that influences the dynamics of the ruble exchange rate. We will consider the effect of the "tax period". The need to make tax payments leads to an increase in the supply of currency from exporters and, as a consequence, to the strengthening of the ruble. Therefore, in the tax periods, there is a relative strengthening of the ruble. Similar conclusions were found in the article by Kiselitsa, Shilova and Liman (2017).

Dvorets and Shevelev (2015) confirmed that the dependence of the ruble exchange rate on the price of Brent crude oil exists and can be characterized as strong and linear. The researchers made this conclusion on the basis of the results obtained using the method of least squares. The price of Brent crude oil and the ruble exchange rate served as variables for this model. This topic was also researched by Liman (2015).

Dreger, Fidrmuc, Kholodilin and Ulbricht (2015) provide evidence on the driving forces of the ruble exchange rate. Their analysis is based on cointegrated VAR models, where fundamental long-run relationships are implicitly embedded. The results indicate that the bulk of the depreciation is caused by the decline of oil prices. In addition, unanticipated sanctions matter for the conditional volatility of the variables involved.

$\mathrm{Wu}$ (2017) believes that the depreciation of the ruble caused large-scale evaporation of Russia's GDP, the decline in corporate competitiveness, and financial instability. While short-term remedy policies were implemented to control the situation, the inevitable economic losses and economic recession have already taken place. It takes a long time to reverse the situation and restore the economy. The similar conclusion was made by other researchers, such as Cheng (2015), Li (2015), and Li (2017).

Blokhina, Karpenko and Guirinskiy (2016) found that another important factor influencing the currency rate of the ruble is a change of key interest rate of the Russian Central Bank. The increase of key interest rate of the Central Bank or security yield in rubles will cause an increase in demand for Russian ruble and will lead to the strengthening of its currency rate. Rather higher key interest rate of the Central Bank will lead to inflow to Russia of the foreign equity, increase the offer of foreign currency and lead to a reduction in the cost of the dollar, causing the strengthening of the ruble. The basis of this research consists of the research by by Amano and Van Norden (1998).

The causes of the ruble fall were also the research topic of numerous works by Russia Studies (2011), Liman and Golubeva (2015), Wang (1993), Xie (2015), Xu (2004), Xu (2014), Yu (2013), Volkov (2013), and Chen (2007).

Gore and Turner (2016), as well as Sosunov and Ushakov (2009), studied the consequences of the sanctions. They admitted, that despite being barred from global capital markets, Russian banks such as Sberbank and VTB had seen a surge in corporate deposits as Russian companies fearful of an escalation in western financial sanctions repatriated cash piles held abroad. The dependence of Russia on foreign capital fell, which allowed reducing the national debt by more than 200 billion US dollars in the last two years. By the end of 2017, GDP growth was projected, which means the exit of the national economy from recession and ruble appreciation in the long term.

Of interest is the idea developed by Rudenko (2016). The results of the study of Russian corporate loan market showed that even some enterprises on the sanctions list, for example, Lukoil, gained the opportunity to borrow currency at lower interest rates than before the introduction of the sanctions regime. In even better conditions were those who did not enter this list: excessive currency liquidity hardened competition in the international credit market for Russian enterprises, favorably affecting the terms of issuing borrowings. 
However, not all researchers adhere to this line. Bykau (2016) and Cao (2014) believe that there is a problem of expensive loans for Russian companies because of the high volatility of ruble. Their research shows that flexible monetary policy of the Central Bank is a necessary but clearly not sufficient condition for overcoming the crisis and resuming the economic growth. This opinion was also supported by Kiselitsa and Shilova (2016).

This article discusses the impact of the volatility of oil prices on the income of economic entities associated with the sale of oil, as well as the importance of the price of oil for stabilizing the exchange rate of the national currency.

\section{Materials and methods}

The research is based on measuring the economic data and estimating the dependence and correlation between them. The following statistical data were used: oil price, currency exchange rates, budget deficit, oil realization earnings, oil export volumes, inflation level, and oil global production volume. The methodological basis of the research relates to such scientific methods of cognition as induction and deduction, analysis and synthesis, graphical method and systematic approach.

The paper analyzes the relationship between the change in the price of oil, ruble exchange rate against the US dollar and volume of Russian oil exports. The reasons for the low price of oil and the consequences for the economy of Russia are indicated. The search and analysis of the factors influencing the price of oil in the world market were carried out.

Moreover, some conclusions and explanations are based on the synthesis of other research containing findings concerning the influence of western sanctions against the Russian economy, the reasons for oil prices volatility and Russian economical expectations.

\section{Results and discussion}

In order to assess the degree of influence of oil prices on the ruble rate, it is necessary to determine how much they correlate with each other. To do this, we have constructed a graph (Figure 1), which reflects the price of one barrel of Brent crude oil in US dollars (Nefttrans.ru 2015; Database of the Central Bank of Russia 2017) and the price of 2000 rubles in US dollars. 


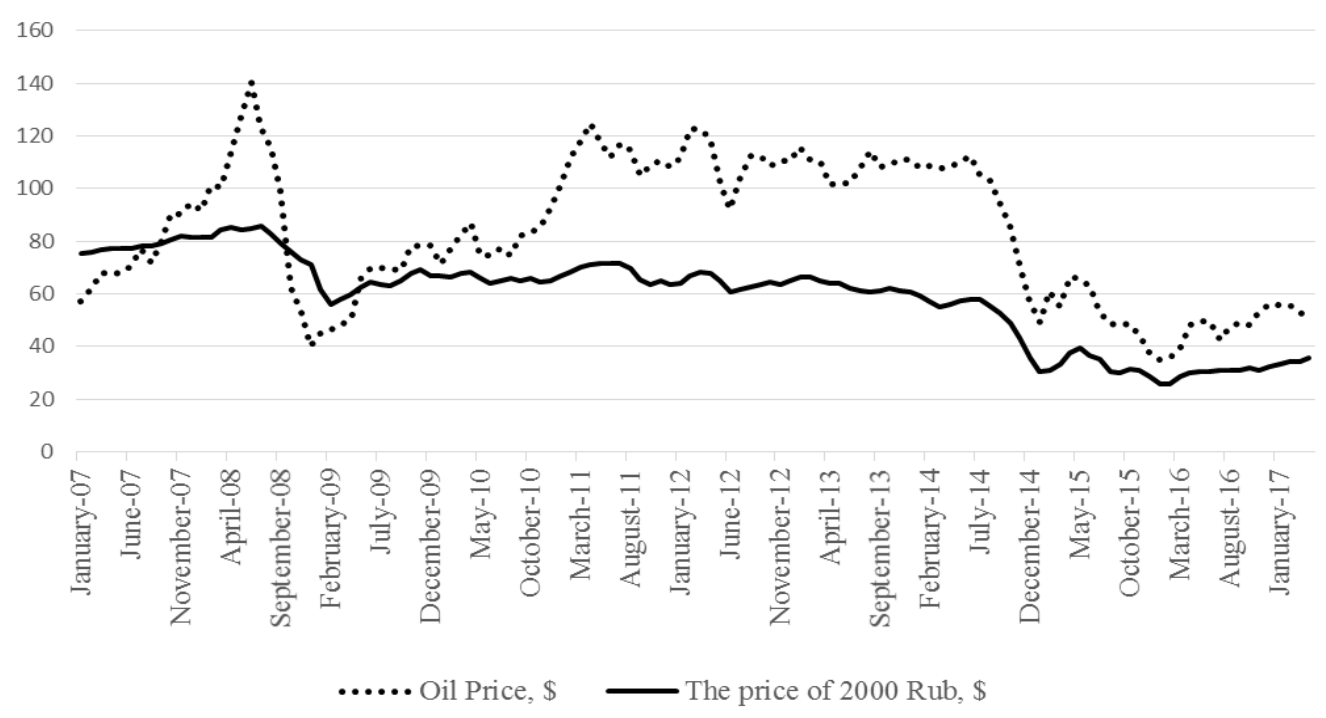

Fig.1. The comparison between the Brent oil price and the Russian ruble exchange rate against the US dollar

According to Figure 1, there is a close relationship between these two values (the correlation is $63.44 \%$ ). During the periods of growth in the price of oil (January 2007 - May 2008, December 2008 - April 2011, January 2016 January 2018), the ruble's price also increased, and in periods of a decline in oil prices (June 2008 - December 2008, June 2014 - January 2016), the price of the ruble also declined. It is worth noting that the rate of change in the price of the ruble is not so dramatic when compared with the change in the price of oil. It reacts more slowly than in the case of oil, but at the same time, the price movement is still rapid.

Thus, it should be concluded that the most important factor affecting the exchange rate of the Russian ruble is the price of Brent crude oil.

There are several reasons for the depreciation of the ruble connected with the fall in the price of oil. The first reason is the significant share of oil exports in the total exports of the Russian Federation. Annually, more than $50 \%$ of the country's foreign exchange earnings come from the sale of oil to other countries. The fall in the price of oil significantly reduces foreign exchange earnings. To maintain a positive trade balance, it is necessary to lower the exchange rate of the national currency. Such a decision will force residents of the country to make purchases of foreign goods and services valued at a smaller amount in foreign currency equivalents.

The second reason is the maintenance of an acceptable level of budget deficit. The dependence of the ruble and oil is not direct but is related to the dollar exchange. The essence of this dependence is that oil is sold for dollars, and the Russian budget should be filled and executed in rubles. Therefore, if the amount of dollars coming from the sale of oil is reduced, in order to "reduce" the budget, one needs to get more rubles, and this can only be done with the help of devaluation. The same rule also applies in the opposite direction: with the growth of the price of oil, the ruble strengthens. The Central Bank can influence the ruble exchange rate by changing the key rate, buying or selling foreign currency or using other instruments at its disposal.

Let us prove that this tendency really exists. This can be done by comparing the proceeds from the sale of oil in rubles (Finam 2017) and the state of the budget deficit (Lenta.ru 2015; 2017; Interfax 2016). 


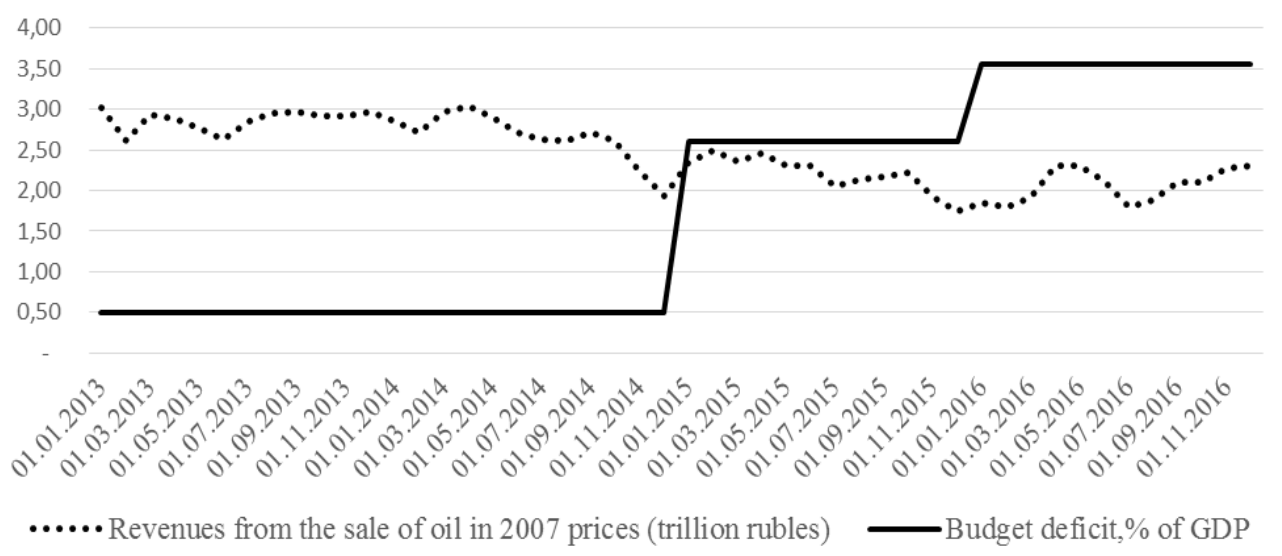

Fig.2. Comparison of revenues from oil sales and budget deficit

As can be seen in Figure 2, the drop in revenue from the sale of oil entailed an increase in the budget deficit. It can be concluded that with an average monthly revenue of 2.75 trillion rubles the budget deficit is minimal $(0.5 \%$ of GDP), and the reduction in the average monthly revenue to 2 trillion rubles leads to an increase in the budget deficit to $2.5 \%$ of GDP in the short term and up to $3.5 \%$ of GDP in the medium term. When oil revenues started to grow in 2017, the budget deficit declined.

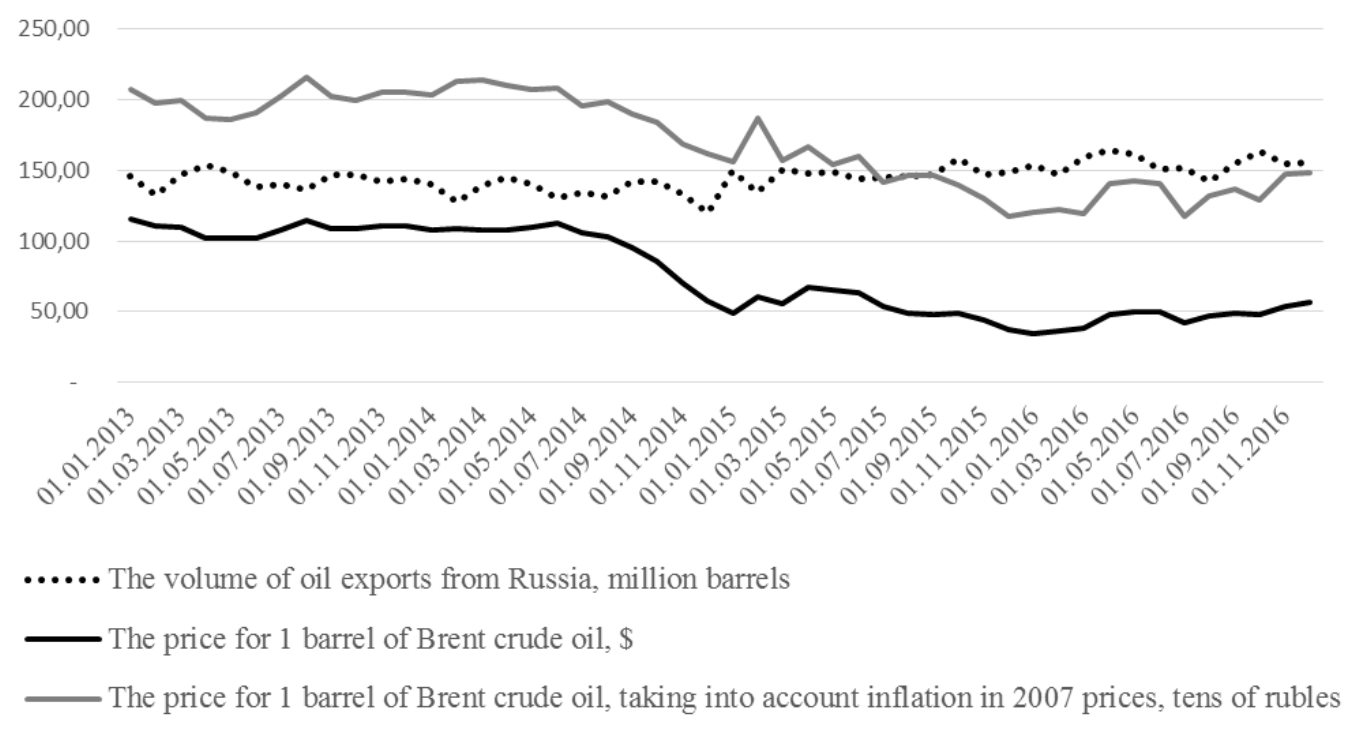

Fig.3. Change in the volume of oil exports depending on the current price of oil

From Figure 3, it can be concluded that the export volumes are inversely proportional to the price of oil: the cheaper the oil is, the more it needs to be extracted and sold in order to stabilize the size of the currency proceeds.

If a $1 \%$ drop in the price of oil entails a depreciation of the ruble by $1 \%$, the country will receive less dollar revenue, but in rubles, the amount will not change compared to the previous period. Of course, in reality, the elasticity of the ruble's exchange rate to the price of oil may differ significantly from this assumption. To determine the ruble losses or the gain from the volatility of the ruble exchange rate and the volatility of the oil price, we will analyze the cash receipts in rubles from the sale of oil. To do this, the price of oil in US dollars 
must be multiplied by the ruble exchange rate and adjusted for inflation. The inflation adjustment is necessary in order to assess the significance of the revenues from the sale of oil in the country relative to the base period (Table 1).

Table 1. Calculation of the price of oil in rubles considering inflation

\begin{tabular}{|c|c|c|c|c|}
\hline Year & $\begin{array}{c}\text { Dollar exchange } \\
\text { rate, rub. }\end{array}$ & $\begin{array}{c}\text { Oil price, } \\
\text { \$ per barrel }\end{array}$ & $\begin{array}{c}\text { The price index } \\
\text { by January 1, 2007 }\end{array}$ & $\begin{array}{c}\text { The price of oil, considering } \\
\text { inflation, rub. }\end{array}$ \\
\hline 2007 & 25.58 & 74.75 & 1.0000 & $1,912.21$ \\
\hline 2008 & 24.86 & 97.28 & 1.1256 & $2,148.25$ \\
\hline 2009 & 31.83 & 64.18 & 1.2759 & $1,601.01$ \\
\hline 2010 & 30.36 & 80.32 & 1.3782 & $1,769.58$ \\
\hline 2011 & 29.39 & 112.41 & 1.5099 & $2,188.21$ \\
\hline 2012 & 31.07 & 110.7 & 1.5728 & $2,055.6$ \\
\hline 2013 & 31.85 & 108.69 & 1.6841 & $2,103.11$ \\
\hline 2014 & 38.47 & 97.64 & 1.7859 & $1,594.26$ \\
\hline 2015 & 61.29 & 53.41 & 2.0533 & $1,374.4$ \\
\hline 2016 & 67.19 & 46.1 & 2.2538 & $1,324.78$ \\
\hline 2017 & 58.15 & 53.92 & 2.367 & \\
\hline
\end{tabular}

Graphically, we represented the calculated indicator in Figure 4.

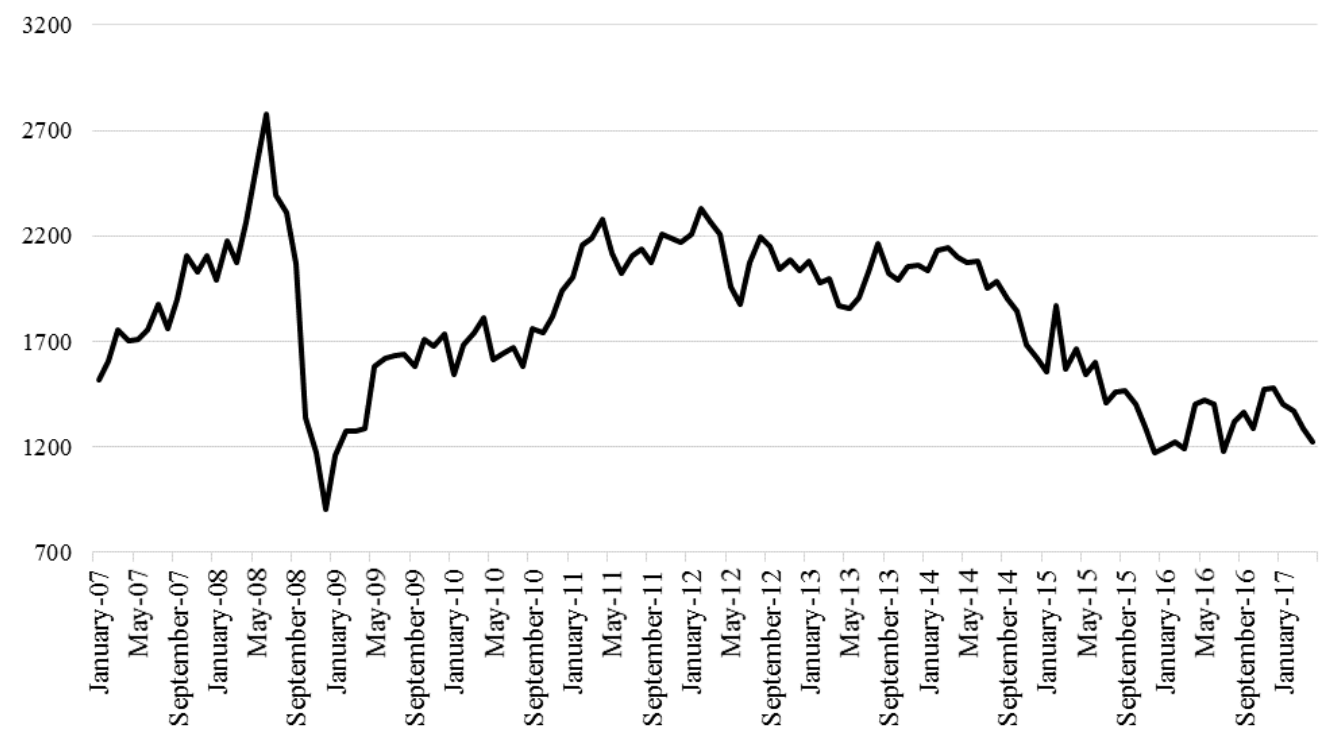

Fig.4. The price of oil in rubles adjusted for inflation

Figure 4 shows that the price of oil in rubles is significantly affected by volatility. At the same time, during the crisis (2008-2009, 2014-2017), the price of oil fell, and during the economic recovery (2007-2008, 2009-2012), it increased.

Since the outbreak of hostilities in Syria to the current time, ruble proceeds from the sale of oil have declined by 1.9 times per barrel. This means that there are still losses in the ruble equivalent, and they are quite substantial.

It should be noted that the decline in dollar revenue per barrel was 2.37 times, and the fall in the ruble exchange rate against the dollar for the period from January 2012 to April 2017 was 53\%. These two factors had a 
significant impact on the change in the price of a barrel of oil in rubles. It turns out that the fall in the Russian national currency compensated for the decline in the price of oil only by $25 \%$.

According to the data from the PROVED (2017), in 2016, fuel and energy products accounted for 58.44\% of Russian exports. This means that, given the unchanged production volume, the country lost about $34 \%$ of its foreign exchange earnings from this.

It is worth noting that most experts identify several reasons for cheaper oil. They include the following:

- The strengthening of the dollar due to the end of the "quantitative easing" of the US Federal Reserve;

- Decreased energy demand due to the recession in Europe and reduced demand growth in Asian countries due to the introduction of less energy-intensive production technologies and stabilization of output;

- The absence of agreement between exporting countries to reduce production.

To prove the first point, we can appeal to the strengthening of the dollar estimated in relation to other world currencies, such as the euro, the Swiss franc, the Japanese yen and the Chinese yuan. In Figure 5, we demonstrate currency exchange rates paired with the dollar for the last five years.

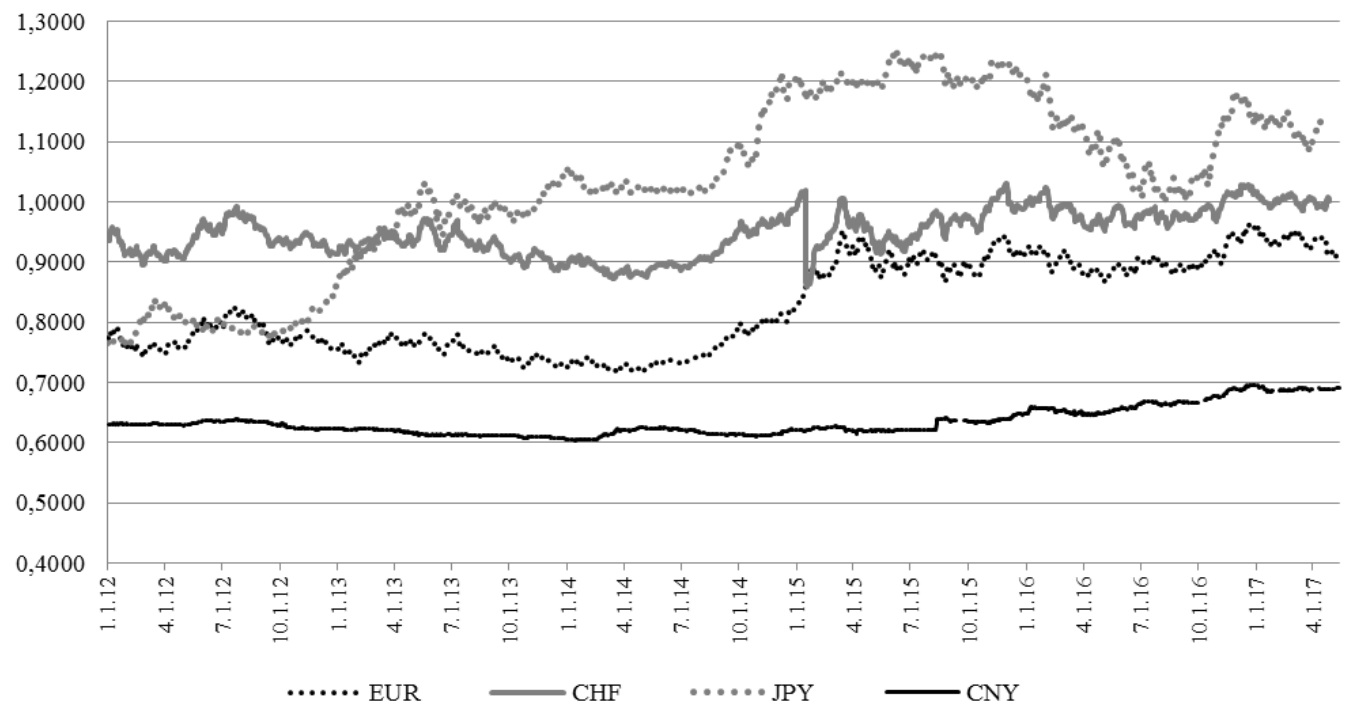

Fig.5. The ratio of the price of the dollar to the prices of other world currencies

As the graph shows, indeed, there is a tendency for the dollar to strengthen against other world currencies. In terms of the dollar's value in pairs with the euro, franc, yen and yuan, the fall in oil prices has been amplified by about $10 \%$.

The price of oil decreases with the increase of supply. Since 2009, the volume of oil production has been steadily increasing (Malina Group 2017). This can be seen in Figure 6. 


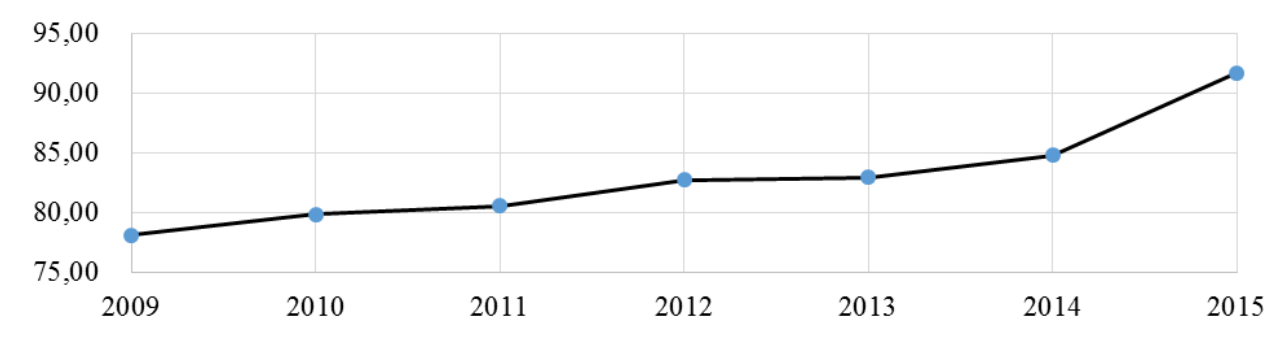

Fig.6. Growth in global oil production, million barrels per day

The decline in oil prices forces the oil-producing countries to increase production to stabilize their revenues. This is necessary to return money invested in the oil industry, and to ensure an acceptable standard of living in countries heavily dependent on oil sales in the foreign market. The increase in supply leads to a further reduction in the price.

Thus, to increase the volume of revenues from the sale of hydrocarbons, it is necessary to reduce the volume of oil production and its supply to the international market for all countries.

It should be noted that oil-producing countries have different prime costs of oil production. Therefore, according to experts, the cost of producing a barrel of oil on the Arabian Peninsula is about 5 US dollars, in Russia - 30-40 US dollars, in the US - 70 US dollars. To date, at a price of 50-55 US dollars per barrel, the production of shale oil in the States is unprofitable, so the supply volume from the US states is not so significant in comparison with what it would be if the price of oil were about \$100-120 per barrel. If the price of oil exceeds $\$ 70$, the countries that produce oil by the standard method will face a new competitor. In view of this, Saudi Arabia and OPEC countries are most likely to prevent oil appreciation of more than 20 US dollars in the short term.

For the Russian economy, the low price of oil leads to diverse consequences. Among them, there are many negative ones: a reduction in the number of goods that can be purchased for import due to a drop in export earnings, which leads to a decrease in the purchasing power of people and a weakening of the ability of companies to purchase equipment and other goods necessary for production. Positive effects from the fall in the price of oil and, as a consequence, the ruble depreciation, also exist: exporters receive foreign exchange earnings, and when converting them into rubles at a low rate, have more financial opportunities for purchasing goods and services in the domestic market, thus driving the domestic economy and stimulating it growth.

The depreciation of the ruble, as was mentioned earlier, occurred to a large extent due to the serious dependence of the Russian economy on the price of oil. It follows, that today the ruble exchange rate can return to the level of 2013 only under two circumstances: if oil prices return to a level close to $\$ 100$ per barrel or the Russian economy is able to overcome raw material dependence and diversify its export supplies in order to obtain greater foreign exchange earnings.

The main factors influencing the supply and demand for oil are as follows:

1. The position of oil-exporting countries. OPEC, which controls most of the oil supply to the market, and which can reduce or increase the volume of oil production by changing quotas.

2. Political instability in oil-rich regions as a factor hampering the supply and transportation of energy.

3. Conditions hampering free trade: natural disasters, bad weather conditions, accidents on pipelines, etc. 


\section{ENTREPRENEURSHIP AND SUSTAINABILITY ISSUES}

ISSN 2345-0282 (online) http://jssidoi.org/jesi/

2019 Volume 7 Number 1 (September)

http://doi.org/10.9770/jesi.2019.7.1(10)

4. Information about world oil reserves. The more oil is found, the greater the volume of potential supply to the market is.

5. The general growth/deterioration of the world economy: the growth of world production requires an increase in the energy.

6. Scientific developments aimed at reducing global energy consumption, especially consumption of petroleum products.

From the aforesaid, it follows that Russia, as a player in the world oil exchange, does not have many ways of influencing the price of oil. This situation implies that only the second way remains a viable option for the Russian government, which involves the diversification of exports. Here too, there are two options for action:

1. The state as a whole encourages non-commodity exports through preferential taxation and discourages commodity exports by increasing export duties. However, this policy will, to a great extent, lead not to the creation of new high-tech industries in different sectors of the economy, but to the creation of oil refineries with the aim of supplying oil products to the foreign market that are not subject to high export duties. The downside of this solution is the problems created for the oil companies, which today are key in feeding the Russian economy.

2. Following from the experience of South Korea and Chile, the state finds several resident companies that are successfully trying to supply non-oil products for export and invites them to participate in a support program. Low tax and export rates and a low-interest rate to attract borrowed funds from state-owned banks under government guarantees will make it possible to build highly efficient competitive production in a short time and, possibly, to take a share of the market in foreign countries. A downside of such a policy is the difficulties associated with antitrust laws, which may result in issues regarding the unequal approach of the state to private companies in the market economy.

Since 2014, under the pressure of foreign sanctions, internal political decisions and common sense, the Government of the Russian Federation have been actively trying to implement a program for diversifying the domestic economy. However, at present the results are disappointing: the volume of raw material exports is growing every year. This is accompanied, primarily, by the fact that currently, the country needs money for its development, and the most effective way to earn it available to the Russian Government is the exportation of energy resources. The volume of oil production annually beats records, thereby increasing, albeit not significantly, the world oil supply. With the falling demand for this energy resource, the price of oil continues to remain at a low level, reducing currency earnings in the country, devaluing the ruble and stimulating price growth.

\section{Conclusions}

As a result of the study, we found that there is a strong correlation $(86.44 \%)$ between the price of a Brent crude oil barrel and ruble exchange rate in US dollars. Moreover, every time when oil prices rise, there is an economic recovery in Russia and when the prices fall, there is an economic downturn.

The price of oil decreases with the increase in supply. An 18\% growth of oil extracting caused the $17 \%$ recession of oil prices (2009-2015).

One of the reasons for oil price decline is the gain of the dollar. There is a tendency of strengthening the dollar against other world currencies. Over the past five years, just like the Euro, the Chinese Yuan, the Swiss Franc and the Japanese Yen, the dollar has become more expensive by about 10\% amid falling oil prices. 


\section{ENTREPRENEURSHIP AND SUSTAINABILITY ISSUES}

ISSN 2345-0282 (online) http://jssidoi.org/jesi/ 2019 Volume 7 Number 1 (September)

http://doi.org/10.9770/jesi.2019.7.1(10)

The problems of the Russian economy are expressed, among other things, in the loss of dollar revenues from oil sales by 2.37 times in the last five years, which significantly affected the trade balance and served as the basis for the devaluation of the ruble. Such a significant decline is ensured by the fall in the price of oil due to a decrease in demand, as well as the strengthening of the dollar against other world currencies. This state of macroeconomic factors led to an increase in the Russian budget deficit from 0.5\% of GDP in 2013 to $3.5 \%$ in 2016.

In order to minimize the budget deficit and stabilize the economic situation, the Government of the Russian Federation regularly increases the export of raw materials in order to obtain greater foreign exchange earnings in the short term. However, the growth of the aggregate supply of oil in the market with falling demand is accompanied by a decrease in the price of energy resources, which leads to a fall in foreign exchange earnings and devaluation of the ruble. To somehow get out of the vicious circle, which began in 2014, under the pressure of foreign sanctions, domestic decisions and common sense, the Government of the Russian Federation has been actively trying to implement a program of diversifying the domestic economy. However, at the moment program hasn't managed to give the desired result: the budget deficit grows from year to year.

The government should pay more attention to supporting entrepreneurship in various spheres of the economy, especially those, in which Russia has competitive advantages over other exporters in the world market.

\section{References}

Amano, R. A.; Van Norden, S. 1998. Oil Prices and the Rise and Fall of The U.S. Real Exchange Rate, Journal of International Money and Finance 17(2): 299-316. https://doi.org/10.1016/S0261-5606(98)00004-7

Blokhina, T. K.; Karpenko, O. A.; Guirinskiy, A. V. 2016. The Relationship between Oil Prices and Exchange Rate in Russia, International Journal of Energy Economics and Policy 6(4): 721-726.

Bykau, A.; Ghodsi, A.; Nezhadhossein, H. 2016. Impact Of Oil Prices On Russian Ruble On Condition Of Floating Exchange Rate Regime, The 5th international Virtual Scientific Conference on Informatics and Management Sciences: March 21-25, Slovakia, 67-69. https://doi.org/10.18638/ictic.2016.5.1.274

Cao, Y. 2014. The Ruble Devaluation Caused the Russian People to Worry, China Industry \& Commence News: 1.

Chen, S. S.; Chen, H. C. 2007. Oil prices and real exchange rates, Energy Economics 29: 390-404.

Cheng, Y. J. 2015. Impacts and Inspirations of the Ruble Crisis, Academic Journal of Russia Studies 2: 39-35.

Dreger, C.; Fidrmuc, J.; Kholodilin, K.; Ulbricht, D. 2015. The Ruble between the Hammer and the Anvil: Oil Prices and Economic Sanctions. Berlin: Deutsches Institut für Wirtschaftsforschung.

Dvorets, N. N.; Shevelev, A. Y. 2015. Modelling Ruble Exchange Rate Dependence from Dollar Oil Price, International Journal of Applied and Fundamental Research 6: 293-295.

Export Of Quotations. 2018, February 21. FINAM, Retrieved from https://www.finam.ru/profile/tovary/brent/export/.

Feklin, V. G.; Shevelev, A. Y. 2015. Modelling Of Dependence of Ruble Exchange Rate on the Price of Oil Taking Into Account Influence of the Tax Period, Fundamental Research 7: 433-435.

Foreign trade of Russia in 2016: figures and facts. 2017. PROVED. Retrieved from http://www.np-srv.ru/stati/vneshnyaya-torgovlya-rossiiv-2016-godu-cifry-i-fakty/ 


\section{ENTREPRENEURSHIP AND SUSTAINABILITY ISSUES}

ISSN 2345-0282 (online) http://jssidoi.org/jesi/ 2019 Volume 7 Number 1 (September)

http://doi.org/10.9770/jesi.2019.7.1(10)

Gore, G.; Turner, M. 2015, November 20. Sanctions Fail to Stem Access to Finance for Russian Corporates. Reuters, Retrieved from https://www.reuters.com/article/russia-sanctions-banks/sanctions-fail-to-stem-access-to-finance-for-russian-corporatesidUSL8N13F1FC20151120

Grafik kotirovok nefti. 2015. NEFTTRANS.RU, Retrieved from http://www.nefttrans.ru/info/quotes/gr.php.

Kiselitsa, E. P.; Shilova, N. N. 2016. Economic technology of enterprise risk management based on information support for their activity, Journal of Internet Banking and Commerce 21(S3).

Kiselitsa, E. P.; Shilova, N. N.; Liman, I. A. 2017. Regional features of the innovative activity for-mation as a determining factor in the development of the Russian economy, Academy of Strategic Management Journal 16(1): 96-111.

Li, J. M. 2015. Causes and Impact of Russian Ruble Crash and Opportunities for Cooperation between China and Russian, Comparative Economic \& Social Systems 1: 46-57.

Li, Z. H. 2011. Analysis of Ruble Internationalization Strategy and China-Russia Trade in Domestic Currency Settlement, Russia Studies 4: 92-104

Liman, I. 2015. Features of pricing in the Russian market of petroleum products. RISC: resources, information, supply, competition 4: 114117.

Liman, I.; Golubeva, O. 2015. Causes of currency fluctuations and their impact on structural changes in the economy, Economics and modern management: theory and practice 41: 88-94.

Official Exchange Rate Dynamics O of a Given Currency. 2017. Database of the Central Bank of Russia. Retrieved from http://www.cbr.ru/currency_base/dynamics.aspx?VAL_NM_RQ=R01235\&date_req1=23.12.2010\&date_req2=1.01.2016\&rt=1\&mode=1

Rudenko, G. 2017. Russian Economy under the Conditions of Sanctions: What It Looks Like, Effective Crisis Management. http://www.info.e-c-m.ru/magazine/95/eau_95_431.htm

Russia Trade in Domestic Currency Settlement. 2011. RUSSIA STUDIES: 92-104.

Sosunov, K.; Ushakov, N. 2009. Determination of the Real Exchange Rate of Ruble and Assessment of Long-Run Policy of Real Exchange Rate Targeting, Journal of the New Economic Association 3-4: 97-121.

The Budget Deficit in Russia in 2016 Amounted To 3.5 Percent of GDP. 2017, 20 January. Lenta.ru, Retrieved from https://lenta.ru/news/2017/01/20/deficit/

The Budget Deficit in the Russian Federation in 2015 Amounted To 2.6\% of GDP. 2016, 22 January. INTERFAX, Retrieved from http://www.interfax.ru/business/491040

The Ministry of Finance Named The Size Of The Budget Deficit In 2014. 2015, 21 January. Lenta.ru, Retrieved from https://lenta.ru/news/2015/01/21/budget/

The Volume of Oil Production by Countries of the World. 2018, February 24. MALINA GROUP, Retrieved from https://malinagroup.com/marketingovye-issledovaniya-rynka/obem-dobychi-nefti-po-stranam-mira/

Volkov, I. I. 2013. The interaction of monetary and fiscal policy: theoretical and practical aspects, public finance, Finance and credit 27(555): 59-63. https://cyberleninka.ru/article/n/vzaimodeystvie-denezhno-kreditnoy-i-byudzhetnoy-politiki-teoreticheskie-i-prakticheskieaspekty

Wang, B. Y. 1993. Why Did the Ruble Fall? Eastern Europe and Central Asia Review 5: 80-82.

Wu, M. 2017. The Impact of Russia's Oil-Dominated Energy Economic Changes on the Exchange Rate of Russian Ruble - Chinese Renminbi, European Scientific Journal 13(22): 173-191. http://dx.doi.org/10.19044/esj.2017.v13n22p173

Xie, L. F. 2015. An Analysis of the Reasons for the Devaluation of Russian Ruble and Its Enlightenment to China, Siberia Studies 3: 3338.

Xu, P. L. 2014. The Crisis and Prospect of Russia's Economy, Russia Studies 2: 85-97. 


\title{
ENTREPRENEURSHIP AND SUSTAINABILITY ISSUES
}

ISSN 2345-0282 (online) http://jssidoi.org/jesi/ 2019 Volume 7 Number 1 (September) http://doi.org/10.9770/jesi.2019.7.1(10)

Xu, X. M. 2004. The Evolution of the Russian Exchange Rate System and the Development of the Foreign Exchange Market, International Economic Review 4: 48-52.

Yu, J. 2013. Research on the Impact of the Ruble Exchange Rate System over the Russian Economy. Russia Studies 6: 108-122.

\author{
Aleksei Anatolievich USTIUZHANIN \\ Irina Aleksandrovna LIMAN \\ ORCID ID: 0000-0001-6640-1462 \\ Elena Petrovna KISELITSA \\ ORCID ID: 0000-0002-1344-9259 \\ Natalia Nikolaevna SHILOVA \\ ORCID ID: 0000-0003-3020-9553 \\ Tatiana Ivanovna LEYMAN \\ ORCID ID: PLEASE INDICATE \\ Author ID: 26641968700
}

ORCID ID: 0000-0001-9909-3291 PLEASE CHECK

Register for an ORCID ID:

https://orcid.org/register

Copyright (C) 2019 by author(s) and VsI Entrepreneurship and Sustainability Center

This work is licensed under the Creative Commons Attribution International License (CC BY).

http://creativecommons.org/licenses/by/4.0/

cc) (†) Open Access 